\title{
Implementasi Sasaran Keselamatan Pasien di Rumah Sakit
}

\author{
Winda Sari Sinaga \\ Windasarisng1701@gmail.com
}

\section{Latar Belakang}

Rumah sakit menjadi salah satu sarana institusi pelayanan kesehatan bagi masyarakat yang pada dasarnya bertujuan untuk menyelamatkan pasien. Rumah sakit wajib memenuhi hak pasien dan pasien memperoleh keamanan dan keselamatan selama berada dalam perawatan di rumah sakit. Keselamatan pasien menjadi hal utama dan terpenting yang perlu diperhatikan dalam memberikan pelayanan kesehatan .

Keselamatan pasien merupakan prioritas yang utama dalam pelayanan kesehatan dan pelayanan keperawatan di rumah sakit sekaligus menjadi aspek paling penting dari manajemen rumah sakit yang berkualitas. Keselamatan pasien atau patient safety merupakan suatu variable penting untuk mengukur dan mengevaluasi kualitas pelayanan keperawatan yang berdampak terhadap pelayanan kesehatan. Penerapan program keselamatan pasien bertujuan menurunkan angka Kejadian Tidak Diharapkan (KTD) yang sering terjadi pada pasien selama dirawat di rumah sakit sehingga sangat merugikan baik pasien sendiri dan pihak rumah sakit.

Sasaran Keselamatan Pasien adalah upaya untuk mendorong peningkatan spesifik dalam keselamatan pasien di intitusi pelayanan kesehatan, salah satunya yaitu rumah sakit. Sasaran ini akan memfokuskan atau menyoroti area yang bermasalah dalam pelayanan kesehatan dan menguraikan tentang solusi atas konsensus berbasis bukti dan keahlian terhadap permasalahan ini.

Sasaran Keselamatan Pasien atau dapat disingkat SKP, merupakan indikator standar dasar yang utama dalam penilaian Akreditasi Rumah Sakit. Sasaran keselamatan pasien merupakan syarat utama untuk diterapkan disemua rumah sakit yang diakreditasi oleh Standar Nasional Akreditasi Rumah Sakit (SNARS). Pada Permenkes Tahun 2011, Nomor 1691, menyatakan ada enam sasaran keselamatan pasien yaitu Ketepatan identifikasi pasien; Peningkatan komunikasi yang efektif; Peningkatan keamanan obat yang perlu diwaspadai; Kepastian tepat-lokasi, tepat- 
prosedur, tepat-pasien operasi; Pengurangan risiko infeksi terkait pelayanan kesehatan; dan Pengurangan risiko pasien jatuh.

Keselamatan pelayanan di rumah sakit salah satunya dimulai dari ketepatan identifikasi pasien. Tahapan pengidentifikasian pasien menjadi awal mula dari segala tindakan yang akan dilakukan tenaga kesehatan kepada klien dan menjadi kunci utama terjadinya keselamatan pasien. Namun nyatanya pada kesalahan karena salah identifikasi pasien cukup tinggi dan kesalahan dalam pengidentifikasian pasien menjadi akar sumber penyebab banyak kesalahan yang terjadi.

Menyadari akan masih tingginya masalah keselamatan pasien di rumah sakit dan bahaya di rumah sakit yang dapat merugikan pasien, rumah sakit perlu untuk fokus terhadap penerpan program keselamatan pasien. Dimana didalam program keselamatan pasien juga menekankan aspek sasaran keselamatan pasien. Yang mana sasaran keselamatan pasien adalah upaya untuk mendorong peningkatan dalam keselamatan pasien dan menurunkan angka Kejadian Tidak Diharapkan (KTD) yang sering terjadi pada pasien selama dirawat di rumah sakit sehingga sangat merugikan baik pasien sendiri dan pihak rumah sakit.

\section{Metode}

Metode yang digunakan oleh penulis dalam jurnal ini adalah Literature review, dengan cara membaca, menganalisis bahan kajian yang relavan dengan pokok bahasan yakni bagaimana pengimplementasian sasaran keselamatan pasien di rumah sakit.

Dimana dengan membaca beberapa jurnal dan bahan kajian terkait lainnya, kemudian menyusun kalimat sendiri yang selanjutnya dituliskan untuk menyelesaikan literature review ini. Bahan kajian yang digunakan yakni berupa textbook, e-book, buku pedoman terkait, tesis dan jurnal online. Adapun jurnal dan referensi yang digunakan pada literature review ini, diterbitkan paling lama tahun 2012, dengan jumlah minimal yaitu 10 referensi.

\section{Hasil}

Berdasarkan hasil dari pencarian dan pengkajian literature dari berbagai sumber, didapatkan bahwa pentingnya pengimplementasian sasaran keselamatan pasien di rumah sakit dan 
pentingnya perawat untuk mengetahui, memahami dan menerapkan sasaran keselamatan pasien di tempat kerja, karna melalui pelaksanaan program keselamatan pasien dapat mencegah terjadinya insiden kecelakaan kerja yang dapat merugikan pasien.

\section{Dari Jurnal Implementasi Sasaran Keselamatan Pasien di Ruang Raat Inap RSU} Kabupaten Tanggerang, (2016) berdasarkan hasilnya dapat disimpulkan bahwa terdapat hubungan terkait antara pendidikan perawat, lama bekerja dan pelatihan patient safety dengan pengimplementasian sasaran keselamatan pasien di rumah sakit. Faktor yang paling signifikan dan berpengaruh besar ialah hubungan pelatihan patient safety dengan pengimplementasian sasaran keselamatan pasien.

Dari Jurnal Analisi pelaksanaan sasaran keselamatan pasien di rawat inap Rumah Sakit Umum Daerah Padang Pariaman (2018), berdasarkan hasilnya dapat disimpulkan bahwa pentingnya untuk terus melakukan pembinaan dan pengawasan kegiatan program keselamatan pasien yang dilaksanakan oleh Tim Keselamatan Pasien Rumah Sakit (TKPRS) secara berkala. Agar program keselamatan pasien yakni sasaran keselamatan pasien dapat terus terpantau pelaksanaanya dan manajemen rumah sakit dapat mengembangkan solusi untuk meningkatkan keselamatan pasien. Dengan penerapan sasaran keselamatan pasien dan pelayanan kesehatan yang baik maka akan tercipta pelayanan yang paripurna yang tentunya juga meningkatkan mutu dan kualitas pelayanan dari rumah sakit.

Dari Jurnal Analisis Sasaran Keselamatan Pasien dilihat dari Aspek Pelaksanaan Identifikasi Pasien dan Keamanan Obat di RS Kepresidenan RSPAD Gatot Soebroto Jakarta, (2017), berdasarkan hasilnya dapat disimpulkan bahwa pentingnya pelaksanaan pengidentifikasian pasien dalam pemberian obat untuk keamanan obat siaga tinggi, dan pengaruh kurangnya pelatihan perawat pelaksana dalam mematuhi SOP. Kesalahan karena kekeliruan identifikasi pasien sering terjadi di hampir semua aspek atau tahapan diagnosis dan pengobatan sehingga diperlukan adanya ketepatan identifikasi pasien. Misalnya penggunaan gelang identifikasi pasien menjadi salah satu cara agar perawat dapat melakukan ketepatan identifikasi pasien. Hal tersebut terutama dimaksudkan untuk dapat mengidentifikasi pasien yang dirawat inap di rumah sakit secara tepat pada saat dilakukannya pelayanan maupun pengobatan. Masih kurangnya penerapan keselamatan pasien di rumah sakit juga disebabkan karna kurangnya perawat dalam mematuhi peraturan dan melaksanakan tindakan menurut SOP. Penerapan 
keselamatan pasien di rumah sakit sepenuhnya belum dilakukan dengan baik dan benar di setiap rumah sakit. Sebab, beberapa tenaga kesehatan juga belum menguasai beberapa hal yang seharusnya menjadi hal yang wajib diberikan kepada pasien.

\section{Pembahasan}

Sasaran Keselamatan Pasien adalah upaya untuk mendorong peningkatan spesifik dalam keselamatan pasien seluruh intitusi pelayanan kesehatan, salah satunya yaitu rumah sakit. Menurut Permenkes Tahun 2011, Nomor 1691, ada enam Sasaran Keselamatan Pasien yaitu Ketetapan identifikasi pasien; Pengkatan komunikasi yang efektif; Peningkatan keamanan obat yang perlu diwaspadai; Kepastian tepat-lokasi, tepat-prosedur, tepat-pasien operasi; Pengurangan risiko infeksi terkait pelayanan kesehatan; dan Pengurangan risiko pasien jatuh.

Sasaran Keselamatan pasien yang pertama dalam Keselamatan pelayanan di rumah sakit dimulai dari ketetapan identifikasi pasien. Ketepatan dalam mengidentifikasi pasien akan berdampak baik pada proses tindakan selanjutnya, tetapi apabila terdapat kesalahan pada tahapan identifikasi pasien maka akan menjadi akar dan sumber masalah di tahapan selanjutnya. Maka dari itu perlunya rumah sakit untuk mengembangkan sistem identikasi pasien menjadi lebih baik agar kesalahan akibat salah identikasi pasien jauh berkurang.

Salah satu penilain SKP adalah pasien diidentifikasi menggunakan dua identitas pasien, tidak boleh menggunakan nomor kamar atau lokasi. Setelah dilakukan brainstorming disepakati bahwa pasien diidentifikasi dengan menggunakan dua identitas dan nomor rekam medis, yaitu menggunakan nama dan alamat. Pemberian gelang tangan (wristband) di lengan, kaki atau tangan menjadi prosedur utama bagi pemberian identitas pasien, terutama bagi pasien yang akn diberikan tindakan invasive, pembedahan, pemberian tranfusi, pemeriksaan imaging, atau pasien yang tidak sadar.

Adapun ketentuan gelang tangan yang pertama yaitu harus ditulis dengan menggunakan huruf balok. Kedua, penulisan secara jelas dan tidak luntur apabila terkena air. Ketiga, harus mencakup paling sedikit dua dari identitas pasien, nama, tanggal lahir, usia, jenis kelamin, ataupun nomor register rekam medis. Meskipun ketentuan penulisan identitas pasien pada gelang sudah 
dilakukan, bukan berarti gelang identitas menjadi satu-satunya cara untuk dapat mencegah kesalahan identikasi pasien.

Faktor utama untuk mencegah terjadinya kesalahan identifikasi pasien adalah ketersediaan dan kepatuhan terhadap SPO dan pelaporan apabila terjadi kesalahan identifikasi pasien. Pelaporan kesalahan identifikasi pasien perlu sebagai dasar perbaikan SPO dan pembelajaran agar tidak terjadi lagi kesalahan identifikasi pasien. Beberapa manfaat yang dapat di peroleh apabila semua tindakan didasarkan pada kebijakan dan prosedur yang telah di tetapkan antara lain: keseragaman dan konsistensi tata kelola, kejelasan terhadap tugas yang dibebankan, mengurangi kesalahan dalam tindakan, menciptakan efisiensi waktu dan biaya, menetapkan pertanggungjawaban dari setiap tindakan, mempermudah menentukan pelatihan, menyiapkan kebijakan dan prosedur yang baru.

Kesalahan lain yaitu salah lokasi, salah prosedur dan salah pasien operasi adalah sesuatu yang mengkhawatirkan dan sering terjadi di rumah sakit. Kesalahan ini merupakan akibat dari komunikasi yang tidak efektif antara anggota tim bedah, kurang/tidak melibatkan pasien didalam penandaan lokasi (site marking) dan tidak ada prosedur untuk verifikas lokasi operasi. Jika komunikasi tidak dilakukan dengan baik akan menjadi ancaman bagi keselamatan pasien. Oleh karena itu kepatuhan petugas perlu diingatkan agar pelaksanaan pasien operasi dapat berjalan optimal. Dan perlunya untuk meningkatkan komunikasi efektif yang baik dalam setiap setiap tindakan independen ataupun tindakan kolabrasi.

Program keselamatan pasien hanya dapat berjalan dengan baik apabila seluruh bagian dari rumah sakit mau ikut andil dalam melakukan dan melaksanakan program keselamatan pasien disetiap kali tindakan pada pasien. Hasil penelitian menunjukkan bahwa sebesar $74.2 \%$ tenaga kesehatan sudah baik dalam menerapkan dan melakukan Sasaran Keselamatan Pasien, yang mana artinya sebagian besar perawat sudah baik dalam mengimplementasikan sasaran keselamatan pasien. Hal ini didapati adanya kaitannya antara kepedulian perawat terhadap implementasi keselamatan pasien dengan terlaksananya Sasaran Keselamatan Pasien dengan baik. Untuk lebih meningkatkan dan mempertahankan pelaksanaan atau implementasi patient safety, maka Rumah Sakit harus melakukan pelatihan patient safety secara berkala dan melakukan monitoring atau evaluasi pelaksanaan patient safety. 
Adanya pengaruh yang signifikan antara pendidikan dan pengetahuan perawat dengan Implementasi Sasaran Keselamatan Pasien di Rumah Sakit. Tingkat pendidikan perawat menjadi salah satu karakteristik individu yang dapat meningkatkan pengetahuan perawat untuk dapat menerapkan patient safety, sehingga dapat menurunkan angka kejadian tidak diharapkan (KTD). Perawat yang memiliki pendidikan terakhir S1 Keperawatan memiliki peluang lebih tinggi untuk mengimplementasikan Sasaran Keselamatan Pasien dengan Baik dibandingkan dengan perawat yang memiliki pendidikan DIII Keperawatan.

Faktor lainnya yang juga sejalan dengan pengaruh pendidikan dan pengetahuan perawat ialah Lama Bekerja atau pengalaman bekerja perawat dengan Implementasi Sasaran Keselamatan Pasien. Lama kerja berkaitan dengan pengalaman kerja, dimana merupakan salah satu faktor kunci dalam keselamatan pasien di rumah sakit, dimana bahwa masa kerja biasanya dikaitkan dengan waktu mulai bekerja, dimana pengalaman kerja juga ikut menentukan produktivitas seseorang. Semakin lama perawat sudah memulai karirnya, maka semakin banyak pengalaman yang sudah didapatkan maka dari itu semakin mudah bagi perawat tersebut untuk mengaplikasikan pengetahuan yang dimilikinya.

Dalam perkembangan Implementasi Sasaran Keselamatan Pasien dirumah sakit, perawat dan tenaga kesehatan lainnya perlu secara berkala diberikan pemantapan pengetahuan mengenai pentingnya pelaksanaan program keselamatan pasien di rumah sakit. Pentingnya rumah sakit untuk terus melakukan pelatihan bagi seluruh tenaga kesehatan maupun non kesehatan yang bekerja di rumah sakit. Pelatihan Patient Safety dalam program Implementasi Sasaran Keselamatan Pasien merupakan serangkaian aktivitas yang dirancang untuk meningkatkan pengetahuan, kemampuan, ketrampilan, sikap dan kinerja sumber daya manusia. Pelatihan untuk meningkatkan pengetahuan dan keterampilan sebagai kriteria keberhasilan program kesehatan secara keseluruhan. Perawat yang sudah mengikuti pelatihan patient safety memiliki peluang yang lebih tinggi untuk mengimplementasikan sasaran keselamatan pasien dengan baik dibandingkan dengan yang belum mengikuti pelatihan patient safety. Banyaknya pelatihan yang diikuti perawat bisa menjadi pengaruh yang kuat dalam menentukan baik tidaknya perawat dalam implementasi sasaran keselamatan pasien. 


\section{Penutup}

Penerapan sasaran keselamatan pasien di rumah sakit harus dilakukan degan kerja sama dari seluruh bagian, baik dokter, perawat dan tenaga kesehatan lainnya dan juga tenaga non medis. Pelaksanaan sasaran keselamatan pasien tidak akan berjalan apabila pada salah satu bagian tidak mendukung terlaksananya program keselamatan pasien di rumah sakit tersebut.

Penerapan sasaran keselamatan pasien yang harus lebih diperhatian dan ditingkatkan ialah pengidentifikasani pasien. Karna melalui tahapan inilah awal dan mulai dari semua proses yang akan diterima pasien. Maka dari itu, apabila terdapat kesalahan pada tahapan identifikasi pasien maka akan menjadi akar dan sumber masalah di tahapan selanjutnya. Pemberian gelang tangan (wristband) di lengan, kaki atau tangan menjadi prosedur utama bagi pemberian identitas pasien. Apabila prosedur identifikasi pasien dilaksanakan dengan benar maka akan mencegah kesalahan dalam melaksanakan proses pelayanan kesehatan. Dan untuk lebih meningkatkan dan mempertahankan implementasi sasaran keselamatan pasien yang sudah baik, maka Rumah Sakit harus melakukan pelatihan patient safety secara berkala dan melakukan monitoring atau evaluasi pelaksanaan patient safety.

\section{Daftar Pustaka}

Setiani, M.D., Zuhrotunnida, dan Syahridal. 2016. Implementasi Sasaran Keselamatan Pasien di Ruang Rawat Inap RSU Kabupaten Tanggerang. Jurnal JKFT. 1 (2) : 59-69.

Neri, Reno Afriza, dkk. 2018. Analisi pelaksanaan sasaran keselamatan pasien di rawat inap Rumah Sakit Umum Daerah Padang Pariaman. Jurnal Kesehatan Andalas. 7 ( 4) : 48-55.

Sakinah, S., Wigati, P.A., \& Arso, S.P. 2017. Analisis Sasaran Keselamatan Pasien dilihat dari Aspek Pelaksanaan Identifikasi Pasien dan Keamanan Obat di RSPAD Gatot Soebroto Jakarta. Jurnal Kesehatan Masyarkat. 5(4) : 145-152.

Diah, A., Salbiah, M., dan Manik. 2015. Pengetahuan tenaga kesehatan dalam sasaran keselamatan pasien di rumah sakit Sumatera Utara. Idea Nursing Journal. 1 (2) : 1-6. 
Bawelle SC, Sinolungan JS, Hamel R. 2013. Hubungan pengetahuan dan sikap perawat dengan pelaksanaaan keselamatan pasien (patient safety) di ruang rawat inap RSUD Liun Kendage Tahuna. Jurnal Keperawatan. 1(1).

Simamora, R. H. (2018). Buku ajar keselamatan pasien melalui timbang terima pasien berbasis komunikasi efektif: SBAR. Medan: USUpress.

Simamora, R. H. (2020). Learning of Patient Identification in Patient Safety Programs Through Clinical Preceptor Models. Medico Legal Update, 20(3), 553-556.

Firawati., Pabuty. A., dan Putra, A. S. 2012. Pelaksanaan Program Keselamatan Pasien di RSUD Solok. Jurnal Kesehatan Masyarakat. 6 (2) : 73-79.

Fadriyanti, Y., Suryanilsih, Y. 2018. Hubungan Jam Kerja dan Karakteristik Perawat Pelaksana dengan Penerapan Sasaran Keselamatan Pasien pada Rumah Sakit di Kota Padang. Jurnal Menara Ilmu. 2(6) : 170-177.

Harus, B.D., Sutriningsih, A. 2015. Pengetahuan Perawat Tentang Keselamatan Pasien dengan Prosedur Keselamatan Pasien di Rumah Sakit (KPRS) di Rumah Sakit Panti Waluya Sawahan Malang. Jurnal Care. 3(1) : 25- 32.

Insani, Tria Harsiwi Nurul, dkk. 2018. Analisis Pelaksanaan Keselamatan Pasien oleh Perawat. Journal of Health Studies. 2 ( 1 ) : 84-95.

Pambudi, Y.D.W., Sutriningsih, A., dan Yasin, D.D.F. 2018. Faktor-faktor yang Mempengaruhi Perawat dalam Penerapan 6 SKP (Sasaran Keselamatan Pasien) Pada Akreditasi JCI (Joint Commision International) di Ruang Rawat Inap Rumah Sakit Panti Waluya Malang. Jurnal Nursing news. 3(8), 729- 746. 